\title{
THE EFFECT OF REPUTATION ON ONLINE REPURCHASE INTENTION OF FRUITS/ VEGETABLES IN INDONESIA WITH EMOTIONAL AND PERCEIVED RISK AS ANTECEDENT: BASED ON THE STIMULUS-ORGANISM-RESPONSE MODEL
}

\author{
Amir Fikri*1, ${ }^{*}$ Rita Nurmalina ${ }^{* *}$, Mukhamad Najib ${ }^{* * *}$, and Megawati Simanjuntak $\left.{ }^{* * * *}\right)$ \\ *) Magister Management Programme, Trisakti University Jakarta \\ Jl Kyai Tapa Gogol Jakarta 11440 \\ ${ }^{* *}$ Departement of Agribusiness, Faculty of Economics and Management, IPB University \\ Jl. Agatis, Campus of IPB Darmaga Bogor 16680 \\ ${ }^{* * *)}$ Department of Management, Faculty of Economics and Management, IPB University \\ Jl. Agatis, Campus of IPB Darmaga Bogor 16680 \\ ${ }^{* * * *)}$ Family and Consumer Science Department, Faculty of Human Ecology, IPB University \\ Jl. Campus of IPB Darmaga Bogor 16680
}

\begin{abstract}
As the trend of online business shopping began to develop it is necessary to have a number of factors anticipated, among others, fresh vegetables/fruit online repurchase intention. The aim of this study is to explain the determinant which influences repurchase intention of customer who buys fruits and vegetables by using e-commerce in Indonesia. Stimulus-Organism-Response Model are used as the basic concepts in this study. The sample collection methods in this study is convenience sampling from 331 respondents who met the criteria. Collected data is analysed using Structural Equation Model (SEM) Lisrel 8.8 and SPSS 24.0 program for all variables. The result of the findings show that there is a significant influence between emotion and risk perceived towards online repurchase intention, and perceived risk give a negative impact to online repurchase intention and emotion. The reputation of e-retailers has no significant effect on perceived risk. Perceived risk has a significant influence on emotion and online repurchase intentions. This study found that emotion significantly influences willingness to online repurchase intention toward fresh vegetables/fruits in Indonesian's e-shopper. This study will be useful to vegetables and fruits e-retailers as well as future researchers.
\end{abstract}

Keywords: online repurchase intention, e-commerce, stimulus-organism-response model, reputation, emotion, perceived risk

\begin{abstract}
Abstrak: Seiring tren belanja online yang mulai berkembang saat ini maka perlu adanya beberapa faktor yang diantisipasi antara lain minat pembelian kembali sayur/buah segar secara online. Tujuan dari penelitian ini adalah untuk menjelaskan faktor-faktor yang mempengaruhi niat pembelian kembali pelanggan yang membeli buah / sayuran dengan menggunakan e-commerce di Indonesia. Stimulus-Organism-Response Model digunakan sebagai konsep dasar dalam penelitian ini. Metode pengumpulan sampel dalam penelitian ini adalah convenience sampling dari 331 responden yang memenuhi kriteria. Data yang terkumpul dianalisis menggunakan Structural Equation Model (SEM) Lisrel 8.8 dan program SPSS 24.0 untuk semua variabel. Hasil temuan menunjukkan bahwa ada pengaruh yang signifikan antara emosi dan risiko yang dirasakan terhadap niat pembelian kembali online, dan risiko yang dirasakan memberikan dampak negatif terhadap niat dan emosi pembelian kembali secara online. Reputasi dari e-retail tidak memiliki pengaruh signifikan terhadap risiko yang dirasakan. Risiko yang dirasakan memiliki pengaruh signifikan terhadap emosi dan niat pembelian kembali online. Studi ini juga menemukan bahwa emosi secara signifikan mempengaruhi keinginan untuk membeli kembali secara online terhadap sayuran / buah segar di e-shopper Indonesia. Studi ini berguna untuk e-retailer sayur/buah serta peneliti di masa depan.
\end{abstract}

Kata kunci: niat pembelian kembali secara online, stimulus-organism-response model, reputasi, emosi, risiko yang dirasakan

${ }^{1}$ Corresponding author:

Email: amirfikri1969@gmail.com 


\section{INTRODUCTION}

An online vegetables and fruits business operates anywhere in the word with the same principle. There is no deviation to the core of its operation. Online vegetables and fruits business is a startup that is growing very fast now especially in Indonesia. Many young entrepreneurs are contemplating to start their online vegetables and fruit selling. The e-commerce business as a whole has increased tremendously over the last few years.

Internet marketing is known as e-commerce. One of these services is online retail, which has been widely described as internet retail, e-retail, or e-tailing (Anderson, 2000), as part of interactive shopping at home (Alba et al. 1997) and with broader terms also called as e-trade or electronic commerce (Daniel \& Klimis, 1999) and e-commerce (Boscheck, 1998). At present there are not many e-commerce in the field of agricultural products marketing in Indonesia. Business through e-commerce platforms in general is a new startup business (infant) and not yet widely known by consumers.

Technological developments and high internet penetration encourage businesses to market their products and services online. Currently there are not many e-commerce in the field of marketing of agricultural products in Indonesia, generally are new startup businesses and not many known by consumers, including: Regopantes, Sayur Box, Kecipir, LimaKilo, TaniHub, and others. Consumers can easily obtain agricultural products by using e-commerce. Agricultural products offered are fresher, quality is guaranteed, and the price is relatively competitive with traditional markets and modern markets such as supermarkets. Literally, the startup is a startup that has just started or has not been operating for a long time. Startup which is often reported at this time is identical and the majority refers to digital companies. "Startup is a formed to search temporary organization repeatable and scalable business model" (Blank, 2010). Marketing of fresh fruits/vegetables is part of marketing agricultural products through the internet is one solution to facilitate consumers to obtain the agricultural commodities they need. Today's healthy lifestyle, which is increasingly leaning towards vegetarianism, is increasingly favored by various generations in various countries in the world including Indonesia. This affects the increase in demand for horticulture products, especially fresh vegetables / fruit. Rachmawati et al. (2018) conducted research on website of Sayur Box to analyze the factors influencing organic fruits and vegetables purchase intention based on WebQual and theory of behaviour and consumer behaviour. The result shows that online purchase intention was affected by attitude and perceived behaviour control (Shabrina et al. 2018; Setiawati et al. 2018).

Reputation has often been suggested as a factor that reduces the risk perceived by consumers in sales organizations (Doney \& Cannon, 1997). According to Chilis and McMackin (1996), companies with good reputation are considered reluctant to endanger their reputation assets by not fulfilling promises and obligations. Consumers consider a smaller risk in purchasing from retailers who have a reputation for providing good service and quality products than from unknown retailers (Purohit \& Srivastava, 2001). The reputation of the company can also reduce consumer concerns with self-disclosure (Andrade et al. 2002). This risk taker was found to limit a range of alternatives to well-known brands with good reputation (Dowling \& Staelin, 1994).

Chang et al. (2011) conducted a study based on the Stimulus-Organism-Response (SOR) model to examine the direct and indirect effects of retail environmental characteristics on the impulse of buying behavior. The three characteristics (ambient, design, and social) of the retail environment affect the positive emotional response of consumers who, in turn, are influenced by the encouraging behavior of buying. This study found a direct effect of (a) environmental characteristics / design of the retail environment on consumer positive emotional responses to the retail environment and (b) consumer positive emotional responses to the retail environment on impulsive buying behavior. Hedonic motivation moderates the relationship between social characteristics of the retail environment and positive consumer emotional responses. According to Mehrabian and Russell (1974), consumer emotions lead to various consumer response behaviors such as purchase intentions as researched by $\mathrm{Ha}$ and Lennon (2010) and approach behavior (Eroglu et al. 2003, Menon and Kahn, 2002). A number of studies have found that consumer emotions play a major role in purchasing behavior, evaluation, and decision-making processes (Ladhari et al. 2008). Research conducted by Baker et al. (1992) found that the emotional state of consumers is positively related to the desire to buy. 
The research conducted by Thakur and Srivastava (2015) shows that consumers' perceived risk of online shopping intention has a negative effect and from five dimensions of perceived risk that has a very high influence is time risk (time risk). Masoud's research (2013) shows that of the six dimensions of perceived risk, only four dimensions have a significant influence on online shopping intention, namely: financial risk, product risk, delivery risk and personal data security risk. The perceived risk dimension that has a strong influence is financial risk. For the other two dimensions such as time risk and social risk does not have a significant effect on online shopping intention. The results of the Mwencha et al. (2014) shows that perceived attributes, perceived risk, and perceived value have a significant influence on online retailing usage. Perceived attributes and perceived value have a positive effect on online retailing usage with a strong influence on perceived attributes. Perceived risk has a negative effect on online retailing usage, so that it can be interpreted that the greater the risk perception, the less likely consumers are to use online retail services in the future.

The approach to solve the problem are integrative review and testing of old theories takes the form of conceptual paper with propositions. The research design used in this study is hypothesis testing. This hypothesis test is used to obtain clarity of relationships between variables after a survey was conducted on respondents through a questionnaire made based on the indicators. The research approach uses quantitative studies, from the Stimulus-Organism-Response model. To fulfill the research objectives, a series of explicit objectives have been developed as follows: analyze the factors that influence the interest of consumer repurchase through e-commerce as a new market chain for marketing fresh vegetables / fruits and to formulate managerial implications in an effort to increase interest in online repurchase of consumers of fresh vegetables/ fruits. This research includes the interest in online repurchase of fresh vegetable/fruit consumers based on an integrated model approach from the StimulusOrganism-Response Model. The subject of this study includes consumers (end users) of fresh vegetables/ fruits who shop through e-commerce.

\section{METHODS}

Data collection takes place from November to December 2018. Respondents are consumers of e-commerce users who shop for fresh vegetables / fruits domiciled in the Jakarta, Depok, Bogor, Tangerang and Bekasi regions. Research uses primary data with online methods using a google form survey that is distributed via email or whatsapps. The sample collection methods that has been used in this study is convenience sampling from 331 respondents who met the criteria. Sample that has been chosen is people who have known, tried or used fresh vegetable/fruits e-commerce and live in five cities in Indonesia. Collected data is analysed using Structural Equation Model (SEM) and SPSS 24.0 program for all variables.

In this study, in order to measure indicator variables, Likert scale rules are used on a scale of 1 to 5 . According to Oei (2010) a Likert scale is a scale that measures the level of agreement or not respondent's agreement to a set of indicators that measure an object. Provisions for a five-point Likert scale are: 1 = Strongly disagree; $2=$ Disagree; $3=$ Enough to agree; $4=$ Agree; and 5= Strongly agree. Descriptions and measurements of variables as shown in Table 1. The research hypotheses are summarized as Table 2 . The research model used in this study is based on the modified Stimulus - OrganismResponse model. Figure 1 shows the conceptual model of research.

Table 1. Operationalization of Variables

\begin{tabular}{lllll}
\hline \multicolumn{1}{c}{ Latent Variables } & Operational Variables Definition & Code & Indicator Variables & $\begin{array}{l}\text { Questionnaire } \\
\text { Refference }\end{array}$ \\
\hline $\begin{array}{l}\text { Reputation (Repu) } \\
\text { (Herbig dan }\end{array}$ & $\begin{array}{l}\text { All previous transactions are } \\
\text { from retailers and require the } \\
\text { Milewicz, 1995) }\end{array}$ & Repu1 & $\begin{array}{l}\text { E-commerce fresh vegetables / fruits } \\
\text { are managed by a reliable company }\end{array}$ & $\begin{array}{l}\text { Doney dan } \\
\text { Cannon } \\
\text { for a long period of time }\end{array}$ \\
& & Repu2 & $\begin{array}{l}\text { Fresh vegetable / fruit e-commerce } \\
\text { site has been known to many people }\end{array}$ \\
& Repu3 & $\begin{array}{l}\text { E-commerce fresh vegetables / fruits } \\
\text { have a good reputation }\end{array}$ \\
& Repu4 & Professional management & \\
\hline
\end{tabular}


Table 1. Operationalization of Variables (Continue)

\begin{tabular}{|c|c|c|c|c|}
\hline Latent Variables & Operational Variables Definition & Code & Indicator Variables & $\begin{array}{c}\text { Questionnaire } \\
\text { Refference }\end{array}$ \\
\hline $\begin{array}{l}\text { Perceived Risk (PR) } \\
\text { Ko et al. (2010) }\end{array}$ & $\begin{array}{l}\text { Potential losses in pursuing } \\
\text { desired results when involved } \\
\text { in online shopping, this is a } \\
\text { combination of uncertainties } \\
\text { with the possibility of serious } \\
\text { consequences }\end{array}$ & & & \\
\hline \multirow{3}{*}{$\begin{array}{l}\text { 1.Financial Risk } \\
\text { (Fin) (Maignan \& } \\
\text { Lukas, 1997) }\end{array}$} & \multirow{3}{*}{$\begin{array}{l}\text { The perception that some value } \\
\text { of money can be lost and other } \\
\text { than that consumers feel about } \\
\text { insecurity regarding the use of } \\
\text { credit cards when conducting } \\
\text { online shopping transactions, } \\
\text { which has been proven to be } \\
\text { a major obstacle to online } \\
\text { purchases }\end{array}$} & Fin1 & $\begin{array}{l}\text { Shopping for fresh vegetables / } \\
\text { fruits online is just a waste of money }\end{array}$ & \multirow{3}{*}{$\begin{array}{l}\text { Almousa } \\
(2011) \text { dan } \\
\text { Javadi et al. } \\
(2012)\end{array}$} \\
\hline & & Fin 2 & $\begin{array}{l}\text { Credit card numbers may not be safe } \\
\text { for transactions shopping for fresh } \\
\text { vegetables / fruits online }\end{array}$ & \\
\hline & & Fin 3 & $\begin{array}{l}\text { You will be charged more for } \\
\text { shopping for fresh vegetables / fruits } \\
\text { online }\end{array}$ & \\
\hline \multirow{3}{*}{$\begin{array}{l}\text { 2.Product Risk } \\
\text { (Prod) (Bhatnagar et } \\
\text { al. 2000; Kim et al. } \\
\text { 2008) }\end{array}$} & \multirow{3}{*}{$\begin{array}{l}\text { The perception that a product } \\
\text { purchased might not work as } \\
\text { expected }\end{array}$} & Prod1 & $\begin{array}{l}\text { Fresh vegetables / fruits do not } \\
\text { match what is ordered online }\end{array}$ & \multirow{3}{*}{$\begin{array}{l}\text { Almousa } \\
(2011) \text { dan } \\
\text { Javadi et al. } \\
(2012)\end{array}$} \\
\hline & & Prod2 & $\begin{array}{l}\text { Difficulty in assessing the quality of } \\
\text { fresh vegetables / fruits purchased } \\
\text { online }\end{array}$ & \\
\hline & & Prod3 & Difficulty to taste $\&$ hold the product & \\
\hline \multirow{4}{*}{$\begin{array}{l}\text { 3.Social Risk } \\
\text { (Sosial)( Li dan } \\
\text { Zhang, 2002) }\end{array}$} & \multirow{4}{*}{$\begin{array}{l}\text { The perception that the } \\
\text { product purchased can result } \\
\text { in disagreement with family or } \\
\text { friends }\end{array}$} & Sosiall & $\begin{array}{l}\text { Vegetables / fruits purchased online } \\
\text { can make the family disagree }\end{array}$ & \multirow{4}{*}{$\begin{array}{l}\text { Almousa } \\
(2011) \text { dan } \\
\text { Javadi et al. } \\
(2012\end{array}$} \\
\hline & & Sosial2 & $\begin{array}{l}\text { Shopping for fresh vegetables / fruit } \\
\text { online can affect your self-image in } \\
\text { the surrounding environment }\end{array}$ & \\
\hline & & Sosial3 & $\begin{array}{l}\text { Shopping for vegetables / fruit } \\
\text { online will reduce the judgment of } \\
\text { others }\end{array}$ & \\
\hline & & Sosial4 & $\begin{array}{l}\text { Shopping for vegetables / fruit } \\
\text { online is not recognized by family / } \\
\text { friends }\end{array}$ & \\
\hline \multirow[t]{3}{*}{$\begin{array}{l}\text { 4. Privacy Risk } \\
\text { (Priv) (Youn, 2009) }\end{array}$} & \multirow{3}{*}{$\begin{array}{l}\text { Information and privacy security } \\
\text { risks related to uncertainty } \\
\text { from personal data information } \\
\text { handled by agencies online and } \\
\text { have access }\end{array}$} & Priv1 & $\begin{array}{l}\text { The risk of personal data will be } \\
\text { exposed }\end{array}$ & \multirow{3}{*}{$\begin{array}{l}\text { Almousa } \\
(2011) \text { dan } \\
\text { Javadi et al. } \\
(2012)\end{array}$} \\
\hline & & Priv2 & $\begin{array}{l}\text { One shop online, it will make you } \\
\text { feel uncomfortable }\end{array}$ & \\
\hline & & Priv3 & Feel insecure when shopping only & \\
\hline \multirow{3}{*}{$\begin{array}{l}\text { 5.Delivery Risk } \\
\text { (Deli) (Dan et al. } \\
\text { 2007) }\end{array}$} & \multirow{3}{*}{$\begin{array}{l}\text { Potential shipping losses are } \\
\text { related to items lost, damaged } \\
\text { goods and items sent to the } \\
\text { wrong address after buying }\end{array}$} & Deli1 & $\begin{array}{l}\text { Risk of not receiving vegetables / } \\
\text { fruit purchased online }\end{array}$ & \\
\hline & & Deli2 & $\begin{array}{l}\text { It is difficult to cancel shopping for } \\
\text { fresh vegetables / fruit online }\end{array}$ & \\
\hline & & Deli3 & $\begin{array}{l}\text { Switching / returning vegetables / } \\
\text { fruit purchased online may have to } \\
\text { wait for a long time }\end{array}$ & \\
\hline \multirow[t]{3}{*}{$\begin{array}{l}\text { 6. Time Risk (Time) } \\
\text { (Hanjun et al. 2004) }\end{array}$} & \multirow{3}{*}{$\begin{array}{l}\text { The perception that the value of } \\
\text { time, comfort, or effort might } \\
\text { be in vain when the product } \\
\text { purchased must be repaired or } \\
\text { replaced / exchanged }\end{array}$} & Time1 & $\begin{array}{l}\text { Shop for fresh vegetables / fruits } \\
\text { online for a long time until the } \\
\text { product is received }\end{array}$ & \multirow{3}{*}{$\begin{array}{l}\text { Almousa } \\
(2011) \text { dan } \\
\text { Zhang et al. } \\
(2012)\end{array}$} \\
\hline & & Time2 & $\begin{array}{l}\text { It takes a long time to exchange } \\
\text { inappropriate products }\end{array}$ & \\
\hline & & Time3 & $\begin{array}{l}\text { Communicating with online sellers } \\
\text { of fresh vegetables / fruit may take a } \\
\text { lot of time }\end{array}$ & \\
\hline
\end{tabular}


Table 1. Operationalization of Variables (Continue)

\begin{tabular}{|c|c|c|c|c|}
\hline Latent Variables & Operational Variables Definition & Code & Indicator Variables & $\begin{array}{l}\text { Questionnaire } \\
\text { Refference }\end{array}$ \\
\hline \multirow{4}{*}{$\begin{array}{l}\text { Emotion (Emosi) } \\
\text { (Rook dan Gardner, } \\
\text { 1993) }\end{array}$} & \multirow[t]{4}{*}{$\begin{array}{l}\text { A sense of happiness or joy in the } \\
\text { shopping experience }\end{array}$} & Emosi1 & $\begin{array}{l}\text { Shopping online is excited because } \\
\text { it can be anytime }\end{array}$ & \multirow{4}{*}{$\begin{array}{l}\text { Beatty dan } \\
\text { Ferrell } \\
(1998)\end{array}$} \\
\hline & & Emosi2 & $\begin{array}{l}\text { Feeling very enthusiastic if you can } \\
\text { shop online (enthusiastic) because it } \\
\text { can be done anywhere }\end{array}$ & \\
\hline & & Emosi3 & $\begin{array}{l}\text { Shopping online is very fun (Fun) } \\
\text { because it's easy }\end{array}$ & \\
\hline & & Emosi4 & Online shopping is pleasure (Joyful) & \\
\hline \multirow{2}{*}{$\begin{array}{l}\text { Online Repurchase } \\
\text { Intention (Rep) } \\
\text { Venkatesh et al. } \\
(2003)\end{array}$} & \multirow{3}{*}{$\begin{array}{l}\text { The intention to buy / repurchase } \\
\text { online effectively by consumers } \\
\text { of products or services in the } \\
\text { future }\end{array}$} & Rep1 & $\begin{array}{l}\text { Intention to continue to buy back at } \\
\text { least the same amount }\end{array}$ & \multirow[t]{3}{*}{$\begin{array}{l}\text { Zarmpou et } \\
\text { al.(2012) }\end{array}$} \\
\hline & & Rep2 & $\begin{array}{l}\text { Intention to buy back as often as } \\
\text { possible }\end{array}$ & \\
\hline Lin et al. (2011) & & Rep3 & $\begin{array}{l}\text { Intention to recommend to others for } \\
\text { purchase }\end{array}$ & \\
\hline
\end{tabular}

Table 2. Research hypotheses \& relationships between variables

\begin{tabular}{cll}
\hline Hyphoteses & Description & Path \\
\hline H1 & Reputation has a significant effect on Emotion & Repu $\rightarrow$ Emosi \\
H2 & Reputation has a significant effect on Perceived Risk & Repu $\rightarrow$ Risk \\
H3 & Perceived Risk has significant effect on Emotion & Risk $\rightarrow$ Emosi \\
H4 & Perceived Risk has a significant effect on Online Repurchase Intention & Risk $\rightarrow$ Rep \\
H5 & Emotion has a significant effect on Online Repurchase Intention & Emosi $\rightarrow$ Rep \\
\hline
\end{tabular}

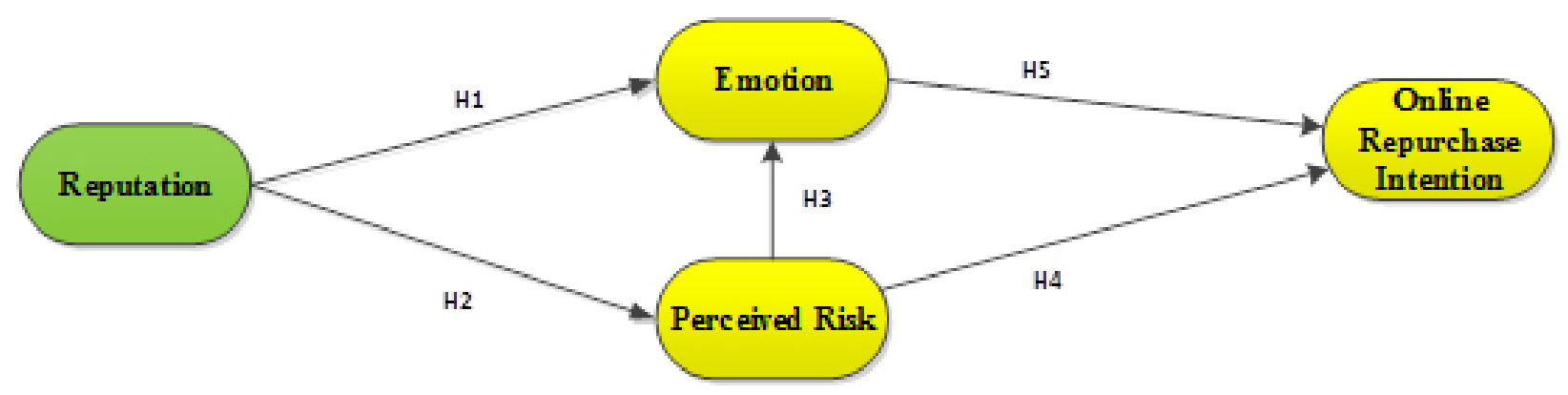

Figure 1. Conceptual research model

\section{RESULTS}

\section{Characteristic Respondents}

The results of this research indicate that from 331 respondents, $25.6 \%$ of respondents were male and $74.4 \%$ of respondents were female. Gen Y (birth 19811994) dominated with a percentage of 46.8 percent. Education owned by respondents was dominated by undergraduate graduates $(\mathrm{S} 1)$ as much as $55.6 \%$. As many as $58.6 \%$ of respondents were married with $58 \%$ of respondents having jobs as private employees. The domicile of the dominant respondent lives in Jakarta as $61.3 \%$.

\section{Respondent Shopping Behavior}

E-shopper of fresh vegetables / fruit was dominated by "A" socio-economic status of $76.7 \%$, with only $63.7 \%$ bought when needed; online transaction media through smart phones as much as $89.7 \%$ Compared to vegetables, respondents bought more fruits as much as $77.9 \%$; respondents were more familiar with "Sayur Box" as e-commerce providers of fresh vegetables/ 
fruits as much as $28.7 \%$; respondents who are familiar with fresh vegetable/fruit e-commerce through social media as much as $44.7 \%$; expenditure in a shopping transaction of Rp100,000-Rp150,000 as much as $37.2 \%$.

\section{Overall Fit Model Test Result}

Overall fit model test was reviewed based on several goodness-of-fit indicators, namely Root Mean Square Error of Approximation (RMSEA), Normed Fit Index (NFI), Non-Normed Fit Index (NNFI), Comparative Fit Index (CFI), Incremental Fit Index (IFI), Relative Fit Index (RFI), Goodness of Fit Index (GFI), and Adjusted Goodness of Fit Index (AGFI). The following Table 3 results of data processing regarding the size of the goodness-of-fit in the research model.

\section{Measurement Model Fit Result}

Based on Table 4, the standardized value of loading factors of each indicator is known to have exceeded 0.5 with an absolute t-value above 1.96, meaning that all measurement indicators reflect latent constructs on the model so that all indicators for each latent construct are considered valid for measurement of latent constructs. Except product risk indicator questions third (Prod46). Table 4 shows the results of the validity test for each indicator.

Unlike the construct validity test, the construct reliability test aims to measure the reliability and internal consistency of the measured variables representing latent constructs. Reliability assessment is divided into two main measurements namely Variance Extracted (VE) and Construct Reliability (CR). According to Hair et al. (2014), latent constructs are said to be reliable if the minimum value of $\mathrm{VE}$ is 0.5 and the minimum value of CR is 0.7 . Based on Table 5, it is known that all major latent variables that affect repurchase intention have VE values $\geq 0.5$ and $C R$ values $\geq 0.7$. Similar to the main latent variable, the indicator variable used as a measure of latent variables has a value of $\mathrm{VE} \geq 0.5$ and $C R$ value $\geq 0.7$. This shows that all variables and indicators are reliable to be used as measurement tools for the latent construct.

\section{Structural Fit Model Result}

In this study, the significance level used was 0.05 with a confidence level of 95 percent thus, the significance of $\mathrm{t}$-value must be $\geq 1.96$. Evaluation of structural models will be carried out on fruits emotion and perceived risk in the online repurchase intention. Based on $t$ value $\geq$ 1.96 which has a significant relationship are H1, H3, H4 and $\mathrm{H} 5$. While $\mathrm{H} 2$ is not significant because it $\mathrm{t}$-value $\leq$ 1.96. The result of structural structural models of SEM is presented in Table 6 and Figure 2.

$\mathrm{R}$-squared indicates the percentage of the variance in the dependent variable that the independent variables explain collectively. Small R-squared values are not always a problem, and high $\mathrm{R}$-squared values are not necessarily good. If R-squared value is low but the statistically significant predictors, it still draw important conclusions about how changes in the predictor values are associated with changes in the response value. Regardless of the R-squared, the significant coefficients still represent the mean change in the response for one unit of change in the predictor while holding other predictors in the model constant. Obviously, this type of information can be extremely valuable.

Table 3. Goodness of fit result

\begin{tabular}{lccc}
\hline Goodness of fit measures & Cut off value & Result & Conclusion \\
\hline Root Mean Square Error of Approximation (RMSEA) & $\leq 0.08$ & 0.076 & Good fit \\
Normed Fit Index (NFI) & $\geq 0.9$ & 0.94 & Good fit \\
Non-Normed Fit Index (NNFI) & $\geq 0.9$ & 0.96 & Good fit \\
Comparative Fit Index (CFI) & $\geq 0.9$ & 0.96 & Good fit \\
Incremental Fit Index (IFI) & $\geq 0.9$ & 0.96 & Good fit \\
Relative Fit Index (RFI) & $\geq 0.9$ & 0.93 & Good fit \\
Goodness of Fit Index (GFI) & $\geq 0.9$ & 0.82 & Marginal fit \\
Adjusted Goodness of Fit Index (AGFI) & $\geq 0.9$ & 0.78 & Marginal fit \\
\hline
\end{tabular}


Table 4. The results of the validity test for each indicator

\begin{tabular}{|c|c|c|c|}
\hline Latent Variables & Indicator Variables & Loading Factor & t-value \\
\hline \multirow[t]{4}{*}{ Reputation } & Repu37 & 0.820 & $17.63 *$ \\
\hline & Repu38 & 0.560 & $10.59 *$ \\
\hline & Repu39 & 0.880 & $19.64 *$ \\
\hline & Repu40 & 0.870 & $19.02 *$ \\
\hline \multirow[t]{3}{*}{ Financial Risk } & Fin41 & 0.580 & \\
\hline & Fin 42 & 0.730 & $9.01 *$ \\
\hline & Fin43 & 0.580 & $9.18^{*}$ \\
\hline \multirow[t]{3}{*}{ Product Risk } & Prod44 & 0.860 & \\
\hline & Prod45 & 0.780 & $13.53 *$ \\
\hline & Prod46 & deleted & \\
\hline \multirow[t]{4}{*}{ Social Risk } & Sosial47 & 0.690 & \\
\hline & Sosial48 & 0.690 & $11.11 *$ \\
\hline & Sosial49 & 0.820 & $12.94 *$ \\
\hline & Sosial50 & 0.880 & $13.41 *$ \\
\hline \multirow[t]{3}{*}{ Privacy Risk } & Priv51 & 0.720 & \\
\hline & Priv52 & 0.870 & $14.98 *$ \\
\hline & Priv53 & 0.870 & $15.05 *$ \\
\hline \multirow[t]{3}{*}{ Delivery risk } & Deli54 & 0.810 & \\
\hline & Deli55 & 0.740 & $14.62 *$ \\
\hline & Deli56 & 0.870 & $17.79 *$ \\
\hline \multirow[t]{3}{*}{ Time Risk } & Time57 & 0.800 & \\
\hline & Time58 & 0.640 & $11.28 *$ \\
\hline & Time59 & 0.570 & $9.99 *$ \\
\hline \multirow[t]{4}{*}{ Emotion } & Emosi60 & 0.870 & \\
\hline & Emosi61 & 0.930 & $25.45^{*}$ \\
\hline & Emosi62 & 0.930 & $25.49 *$ \\
\hline & Emosi63 & 0.890 & $22.68 *$ \\
\hline \multirow[t]{3}{*}{ Online Repurchase Intentions } & Rep64 & 0.920 & \\
\hline & Rep65 & 0.870 & $21.48 *$ \\
\hline & Rep66 & 0.820 & $20.32 *$ \\
\hline
\end{tabular}

Note $\left.:^{*}\right)$ Significant at t-value $\geq 1.96$, valid

Table 5. The results of the reliability test for latent constructs

\begin{tabular}{|c|c|c|c|c|}
\hline \multirow{2}{*}{ Laten Variables } & \multirow{2}{*}{ Indicator Variables } & \multicolumn{2}{|c|}{ Reliability Test } & \multirow{2}{*}{ Conclusion } \\
\hline & & $\mathrm{VE} \geq 0.5$ & $\mathrm{CR} \geq 0.70$ & \\
\hline Reputation & repu37-repu40 & 0.629 & 0.869 & Reliable \\
\hline Financial Risk & fin $41-$ fin 43 & 0.500 & 0.666 & Reliable \\
\hline Product Risk & pro44-prod45 & 0.674 & 0.805 & Reliable \\
\hline Social Risk & sosial47-sosial50 & 0.600 & 0.856 & Reliable \\
\hline Privacy Risk & priv51- priv53 & 0.677 & 0.862 & Reliable \\
\hline Delivery Risk & deli54-deli56 & 0.648 & 0.846 & Reliable \\
\hline Time Risk & time57-time59 & 0.500 & 0.713 & Reliable \\
\hline Emotion & emosi60-emosi63 & 0.822 & 0.948 & Reliable \\
\hline Online Repurchase Intention & rep64-rep66 & 0.759 & 0.904 & Reliable \\
\hline
\end{tabular}


Table 6. Path coefficient value, t-value, and significance of hypotheses

\begin{tabular}{clccc}
\hline \multirow{2}{*}{ Hyphoteses } & \multicolumn{1}{c}{ Path } & $\begin{array}{c}\text { Path coefficient } \\
\text { value }(\beta)\end{array}$ & $\begin{array}{c}\mid \text { t-value } \geq 1.96 \mid \\
\text { Hypotheses } \\
\text { decision }\end{array}$ \\
\hline H1 & Reputation $\rightarrow$ Emotion & 0.50 & 8.77 & Accepted \\
H2 & Reputation $\rightarrow$ Perceived Risk & -0.066 & -1.09 & Unaccepted \\
H3 & Perceived Risk $\rightarrow$ Emotion & -0.14 & -2.60 & Accepted \\
H4 & Perceived Risk $\rightarrow$ Online Repurchase Intention & -0.11 & 2.55 & Accepted \\
H5 & Emotion $\rightarrow$ Online Repurchase Intention & 0.80 & 15.42 & Accepted \\
\hline
\end{tabular}

Note *) Significant at t-value $\geq 1.96$.

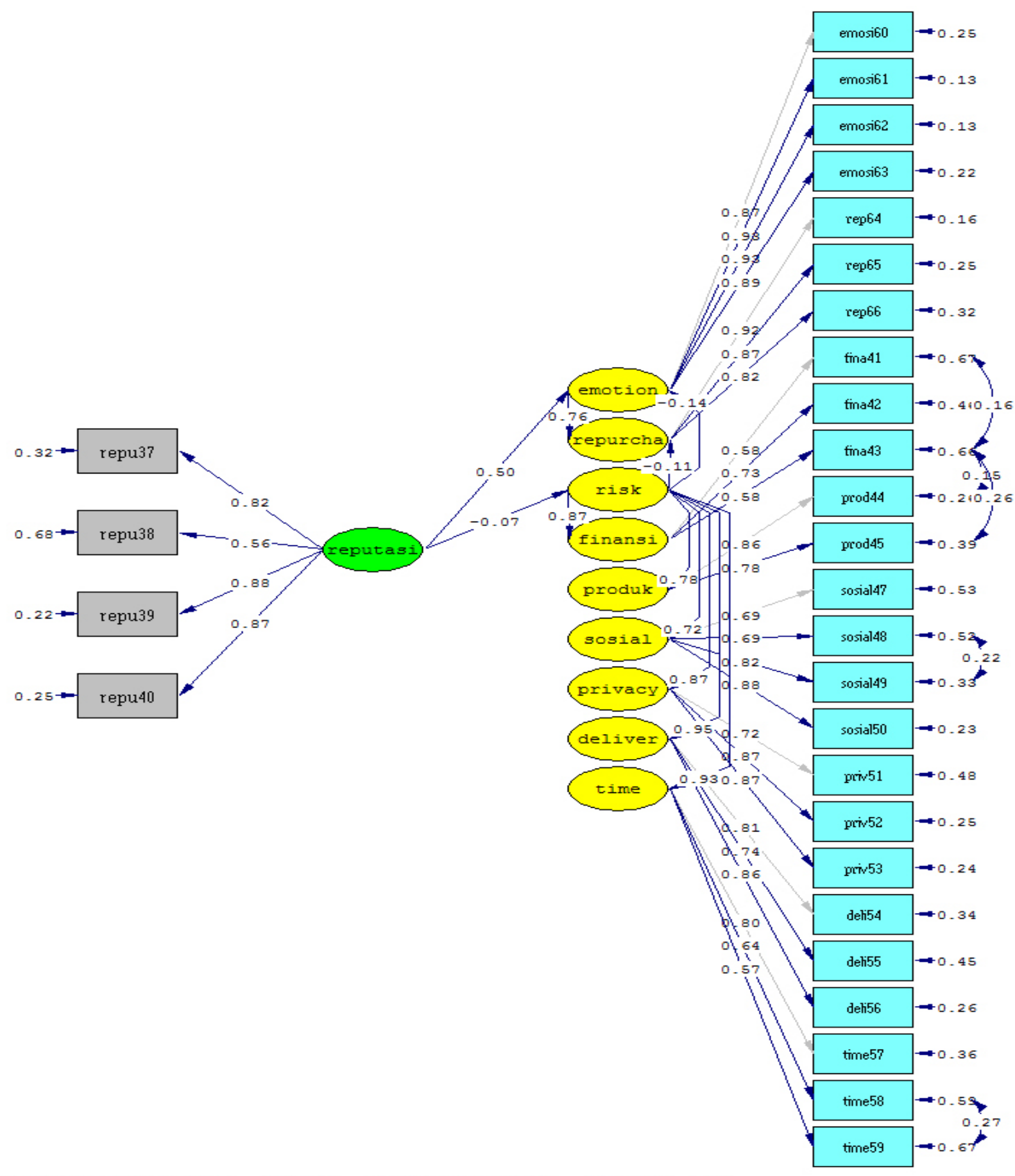

Chi-Square=1055.14, df=361, P-value=0.00000, RMSEA=0.076

Figure 2. Analysis of SEM Model on fresh vegetables/fruits repurchase intention 
The emotion R-square model (Table 7) value is 0.280 , which means that $28 \%$ of emotion diversity is able to be explained by reputation, and perceived risk, the remaining $72 \%$ is explained by other factors outside the model. The online repurchase intention $\mathrm{R}$-square value is 0.610 , which means that $61 \%$ of online repurchase intentions can be explained by emotion, perceived risk, the remaining 39\% is explained by other factors outside model. The R-square value of perceived risk model is 0.0044 which means that $0.44 \%$ of diversity of perceived risk can be explained by reputation, the remaining $99.56 \%$ is explained by other factors outside the model. Results suggest that the conceptualized model captures the decision making process, and that reputation toward risk have independent effects on consumer acceptance. However, the effect from risk perception is lower in intensity because reputation is no significant effect on perceived risk. Hence, besides a relatively lower risks aversion level, e-shopper who reveal repurchase intention of fresh vegetables/fruits tend to perceive fewer risks.

Table 7. Adjusted R-square value of SEM results

\begin{tabular}{lc}
\hline Laten Variable & $\mathrm{R}^{2}$ Value \\
\hline Emotion & 0.280 \\
Perceived Risk & 0.0044 \\
Online Repurchase Intentions & 0.610 \\
\hline
\end{tabular}

Effects of Reputation on Emotion

The effect test results show that reputation variable has influenced on emotion with path coefficient value of 0.50 and $t$-value 8.77. This shows that the higher the reputation of the e-commerce, the emotion from e-shopper will increase. The results of this study are consistent with the research of Lee and Shavitt (2006) that store reputation will affect the perception of online e-commerce sites. Jin et al. (2008) found a significant positive relationship between company reputation, e-satisfaction and e-trust.

\section{Effect of Reputation on Perceived Risk}

The results of the testing of the effect show that reputation variables has not influence on perceived risk with the path coefficient value of -0.066 and $t$-value -1.09 . The results of this study are different from the results of Purohit and Srivastava's (2001) study with significant influence where consumers consider smaller risks in purchases from retailers who have a good reputation for service and product quality than from unknown retailers.

\section{Effect of Perceived Risk on Emotion}

The results of the influence testing show that the perceived risk variable has a negative effect on emotion with the path coefficient value of -0.14 and $t$-value -2.60. This shows that the higher perceived risk, the online repurchase intention will decrease. The results of this study are the same as the research conducted by Juniwati (2014) stating that perceived risk is quite significant for emotion and also attitude.

Effect of Perceived Risk Variables on Online Repurchase Intention

Testing the fifteenth hypothesis is about the effect of perceived risk variables on the online repurchase intention. The results of the influence testing show that the perceived risk variable has a negative effect on repurchase intention with the path coefficient value of -0.11 and $t-$ value 2.55 . This shows that the higher perceived risk, the online repurchase intention will decrease This research produced the same results as Gerrard and Cunningham (2003); Kim and Forsythe (2010) which states that perceived risk on online shopping is felt to be an obstacle in conducting internetbased transactions and thus it will affect the choice of consumers to shop online.

\section{Effect of Emotion on Online Repurchase Intention}

The test results show that the emotion variable has a $t$ positive effect on repurchase intention with a path coefficient of 0.80 and $t$-value of 15.42 . This shows that the higher the emotion, the online repurchase intention will increase. The results of this study are in line with the research conducted by Baker et al. (1992) found that the emotional state of consumers is positively related to repurchase intention.

\section{Indirect Effects Between Variables}

In testing the indirect effect, it is known that reputation has a significant effect on online repurchase intention with path coefficient values of -0.11 and $t$-value -2.58 . This shows that the lower reputation, the online repurchase intention will decreased. 


\section{Managerial Implications}

The emotional factors of e-shopper and the reputation of e-retailers provide the biggest influence of all other significant variables on the intention to repurchase vegetables / fresh fruit online. Marketing strategies that can be built by e-retailers to foster positive emotions (excited, enthusiastic, fun and joyful) for e-shopper, among others, by making an online shopping application that is user friendly that can be used anywhere and anytime. Besides that, it is also necessary to build a community of e-shopper fresh vegetables/ fruits by using social media such as Facebook, Twitter, Instagram, linked in and others, and can also be a medium of communication between sellers, buyers and other e-shopper communities that can be an evaluation of a product or services. In addition, building an online community using social media is one of the online marketing strategies that can be done by marketing managers through the provision of discounts, free gifts, and free shipping that directly impact the repurchase intention.

Strategies to build reputation from e-retailers to foster interest in e-shopper repurchases can be done through professional management, including using domain. co.id; accept cash on delivery with terms and conditions in effect. Domain.co.id is the official domain used by local websites in Indonesia. A website using this domain certainly has a high trust value because it means that e-retailers are serious about working on their business. This type of domain can be trusted because e-retailers must have official documents such as a Trading Business License (SIUP), manager's identity and other supporting documents and also a statement that the domain registered is different from the company name. Whereas Cash on Delivery (COD) will strengthen e-shopper's trust that e-shopper will not commit fraud, the product will be received according to the order and on time.

\section{CONCLUSIONS AND RECOMMENDATIONS}

\section{Conclusions}

The result of this research found of five hypotheses prepared, there is one unsupported hypotheses that is reputation has no significant effect on perceived risk; and four hypotheses are supported that are consist of reputation has a significant effect on emotion; perceived risk has significant effect on emotion; perceived risk has a significant effect on online repurchase intention and emotion has a significant effect on online repurchase intention.

The reputation variable has positive influenced on emotion, this shows that the higher the reputation, the emotion from e-shopper will increase. The perceived risk variable has a significant negative effect on emotion, this shows that the higher perceived risk, the emotion will decrease. Then perceived risk has a negative effect on emotion, it means that the higher perceived risk, the online repurchase intention will decrease. The perceived risk variable has a negative effect on repurchase intention, this show that the higher perceived risk, the online repurchase intention will decrease. This study also found that emotion is significantly influences willingness to online repurchase intention toward fresh vegetables/fruits in Indonesian's e-shopper.

\section{Recommendations}

Subsequent research is expected to be able to consider other factors that can influence the intention to repurchase online (besides the variables in this study, including customer service) and post-purchase experiences, these variables are assessed has an influence on consumer intentions for interest in repurchasing online. Further research can take other cities with different characteristics such as large cities, provincial capitals on the island of Java or outside the island of Java.

\section{REFERENCES}

Alba J, Lynch J, Weitz B, Janisqewski C. 1997. Interactive home shopping: Consumer, retailer, and manufacturer incentives to participate in electronic marketplaces. Journal of Marketing 61(3): 38-53. https://doi.org/10.2307/1251788.

Almousa M. 2014. The influence of risk perception in online purchasing behavior: Examination of an early stage online market. International Review of Management and Business Research 3(2).

Andrade, EB, Kaltcheva V, Weitz B. 2002. Selfdisclosure on the web: The impact of privacy policy, reward, and company reputation. Advances in Consumer Research 29: 350-3.

Anderson L. 2000. Retail and Wholesale Industry. Austin: Hoover's Online. 
Baker J, Grewal D, Levy M. 1992. An experimental approach to making retail store environment decisions. Journal of Retailing 68(4):445-460.

Beatty SE, Ferrell ME. 1998. Impulse buying: Modeling its precursor. Journal of Retailing 74(2): 169-91. https://doi.org/10.1016/S00224359(99)80092-X.

Bhatnagar A, Misra S, Rao HR. 2000. On risk, convenience, and internet shopping behavior. Associationfor Computing Machinery. Communications of the ACM 43(11): 98-110. https://doi.org/10.1145/353360.353371.

Blank S. 2010. What's a startup? First principles. https://steveblank.com/2010/01/25/.[accessed on 2018 Juni 6]

Boscheck R, 1998. New media economics are transforming consumer relations. Long Range Planning 31: 873-878. https://doi.org/10.1016/ S0024-6301(98)80023-X.

Chilis TH, McMackin JF. 1996. Integrating variabel risk preferences, trust, and transaction cost economics. The Academy of Management Review 21(1): 73-99. https://doi.org/10.5465/ amr.1996.9602161566.

Chang HJ, Eckman M, Yan RN. 2011. Application of the Stimulus-Organisme-Response Model to the retail environment: the role of hedonic motivation in impulse buying behavior. The International Review of Retail, Distribution and Consumer Research 21(3): 233-249. https://doi. org/10.1080/09593969.2011.578798.

Daniel E, Klimis GM. 1999. The impact of electronic commerce on market structure: An evaluation of the electronic market hypothesis. European Management Journal 17(3): 318-325. https:// doi.org/10.1016/S0263-2373(99)00011-0.

Dan Y,Taihai D, Ruiming L. 2007. Study of Types, Resources and Their Influential Factors of PerceivedRisks in Purchase Online. Journal of Dalian University of Technology 28 (2): 13-19.

Doney PM, Cannon JP. 1997. An examination of the nature of trust in buyer-seller relationships. Journal of Marketing 61: 33-51. https://doi. org/10.1177/002224299706100203.

Dowling GR. Staelin R. 1994. A model of perceived risk and intended risk-handling activity. Journal of Consumer Research 21(1):119-34. https://doi. org/10.1086/209386.

Eroglu SA, Davis I, Mahleit KA. 2003. Empirical testing of a model of online store atmospheric and shopper responses. Psychology and Marketing
20(2): 139-150. https://doi.org/10.1002/ mar. 10064

Gerrard P, Cunningham JB. 2003. The diffusion of Internet banking among Singapore consumers. International Journal of Bank Marketing 21(1): 16-28. https://doi. org/10.1108/02652320310457776.

Hair JF, Black WC, Babin BJ, Anderson RE. 2014. Multivariate Data Analysis, seventh edition. New Jersey:Prentice Hall, Upper Saddle River.

HaY,Lennon SJ.2010. Effects of site design on consumer emotions: role of product involvement. Journal of Research in Interactive Marketing 4 (2): 80-96. https://doi.org/10.1108/17505931011051641.

Hanjun K, Jaemin J, JooYoung K, Sun Wook S. 2004. Cross cultural differences in perceived risk of online shopping. Journal of Interactive Advertising 4(2): 20-29. https://doi.org/10.1080 /15252019.2004.10722084.

Herbig P, Milewics J. 1993. The relationship of reputation and credibility to brand success. Journal of Consumer Marketing 10(3): 18-24. https://doi.org/10.1108/EUM0000000002601.

Javadi M, Dolatabadi H. Nourbakhsh M, Poursaeedi A, Asadollahi A. 2012. An Analysis of factors Affecting on Online Shopping Behaviour of consumers. International Journal of Marketing Studies 4(5): 81-98. https://doi.org/10.5539/ ijms.v4n5p81.

Jin B, Park JY, Kim, J. 2008. Cross-cultural examination of the relationships among firm reputation e-satisfaction, e-trust and e-loyalty. International Marketing Review 25: 324-337. https://doi. org/10.1108/02651330810877243.

Juniwati. 2014. Influence of perceived usefulness, ease of use, risk on attitude and intention to shop online. European Journal of Business and Management 6(27)

Kim J, Forsythe S. 2010. Factors affecting adoption of product virtualization technology for online consumer electronics shopping.International Journal of Retailing and Distribution Management 38(3): 190-204. https://doi. org/10.1108/09590551011027122.

Kim D, Ferrin D, Rao J. 2008. A trust-based consumer decision-making model in electronic commerce:The role of trust, perceived risk, and their antecedents. Decision Support Systems 44:544-564. https://doi.org/10.1016/j. dss.2007.07.001.

Ko H, Jung J, Kim J, Shim SW. 2004. Cross cultural 
differences I perceived risl of online shopping. Journal of Interactive Advertising (4)2: 20-29. https://doi.org/10.1080/15252019.2004.107220 84.

Li N, Zhang P. 2009. Consumer and behavior: An assessment of research. Information System proceeding of Eight Americas Conference

Lin CH, Lee SH, Horng DJ.2011. The effects of online reviews on purchasing intention: the moderating role of need for cognition. Social Behavior and Personality 39: 71-82. https://doi.org/10.2224/ sbp.2011.39.1.71.

Ladhari R, Morales M, Brun I. 2008. Determinants of dining satisfaction and post dining behavioura; intention. International Journal of Hospitality Management 27(4): 563-573. https://doi. org/10.1016/j.ijhm.2007.07.025.

Lee K, Shavitt S. 2006. The use of cues depend on goals: Store reputation affects product judgement when social identity goals are salient. Journal of Consumer Psychology 16(3): 260-271. https:// doi.org/10.1207/s15327663jcp1603_8.

Maignan I, Lukas, BA. 1997. The nature and social Uses of the internet: a qualitative investigation. Journal of Consumer Affairs 31(2): 346-371. https://doi.org/10.1111/j.1745-6606.1997. tb00395.x.

Masoud EY. 2013. The effect of perceived risk on online shopping in Jordan. Eropean Jurnal of Business and Management 5(6).

Mehrabian A, Russell JS. 1974. An approach to Environmental Psychology. Cambridge: M.I.T. Press.

Menon S, Kahn B. 2002. Cross-category effects of induced arousal and pleasure on the internet shopping experience. Journal of Business Research 78:31-40. https://doi.org/10.1016/ S0022-4359(01)00064-1.

Mwencha PM, Muathe SM, Thuo JK. 2014. Effects of perceived attributes, perceived risk and perceived value on usage of online retailing services. Journal of Management Research 6(2): 140-161. https://doi.org/10.5296/jmr.v6i2.5224.

Oei I. 2010. Riset Sumber Daya Manusia. Jakarta: PT Gramedia Pustaka Utama

Purohit D, Srivastava J. 2001. Effect of manufacturer reputation, retailer reputation, and product warranty on consumer judgments of product quality: A cue diagnosticity framework. Journal of Consumer Psychology 10(3):123-134. https:// doi.org/10.1207/s15327663jcp1003_1.

Poel D, Leunis, J. 1995. The impact of price, branding and money-back guarantee on store choice. Proceedings of the 8th International Conference on Research in the Distributive Trades. Universita` Bocconi, Milan, Italy.pp. B4.21-9

Rachmawati NA, Suroso AI, Ramadhan A. 2018. Factors influencing the purchase intention in Online organic fruit and vegetables stores. Jurnal Manajemen \& Agribisnis 15(3). http://dx.doi. org/10.17358/jma.15..209

Rook WD, Gardner MP. 1993: In the mood: Impulse buyings affective antecedents. In Janeen ArnoldCosta and Russel W Belk (Eds.) Research in Consumer Behavior. 6. Greewich CT: JAI Press: $1-28$.

Setiawati H, Hartoyo, Simanjuntak M. 2018. Analysis on Intention of Purchasing Organic Foods by The Undergraduate Students of IPB Using The Theory of Planned Behavior Approach. Jurnal Manajemen \& Agribisnis 15 (2): 198-207. http:// dx.doi.org/10.17358/jma.15.2.198.

Shabrina Z, Yuliati LN, Simanjuntak M. 2018). The Effects of Religiousity, Pricing and Corporate Image on The Attitude and The Intention to Use Sharia Micro Financing. Indonesian Journal of Business and Entrepreneurship 4(2) : 196-205. https://doi.org/10.17358/ijbe.4.2.197.

Thakur R, Srivastava M. 2015. A study on the impact of consumer risk perception and innovativeness on online shopping in India. International Journal of Retail \& Distribution Management 43(2): 148-166. https://doi.org/10.1108/IJRDM-062013-0128

Venkatesh V, Morris MG, Davis FD, Davis GB. 2003. User acceptance of information technology: Toward a unified view. MIS Quarterly 27: 425478. https://doi.org/10.2307/30036540.

Youn, S. 2009. Determinants of online privacy concern and its influence on privacy protection behaviors among young adolescents. Journal of Consumer Affairs 43(3): 389 - 418. https://doi.org/10.1111/ j.1745-6606.2009.01146.x.

Zarnpou T, Saprikis V, Markos A, Vlachopoulou M. 2012. Modelling user's acceptamce of mobile services. Electronic Commerce Research 12: 225-248. https://doi.org/10.1007/s10660-0129092-х. 